\title{
Treating Produced Water Using Induced Air Flotation: The Effect of Ethanol on Conditioning and Flotation of PAHs in the Presence of Tween 80
}

\author{
Salima Chebbi ${ }^{1}$, Atmane Allouache ${ }^{2}$, Marián Schwarz ${ }^{3 *}$, \\ Hayet Belkacemi ${ }^{1}$, Djoudi Merabet ${ }^{1}$ \\ ${ }^{1}$ Materials Technology and Process Engineering Laboratory, University of Bejaia, Bejaia, Algeria \\ ${ }^{2}$ Applied Hydraulic and Environment Research Laboratory, University of Bejaia, Bejaia, Algeria \\ ${ }^{3}$ Faculty of Ecology and Environmental Sciences, Department of Environmental Engineering, \\ Technical University, Zvolen, Slovakia
}

Received: 22 February 2018

Accepted: 16 April 2018

\begin{abstract}
Induced air flotation (IAF) was used to recover the total polycyclic aromatic hydrocarbons $\left(\mathrm{PAH}_{\mathrm{tot}}\right)$ from produced water (PW), a real oilfield effluent sampled from the hydrocarbon storage tanks at SONATRACH of Bejaia. Tween 80 was used as a collector at a test concentration of $0.5 \%$ $(\mathrm{V} / \mathrm{V} \%)$ and ethanol was used as a frother at a test dosage of $0.5 \mathrm{~mL} / 1000 \mathrm{~mL}$ of PW. The natural presence of $\mathrm{NaCl}$ at greater concentrations may improve the removal efficiency of $\mathrm{PAH}_{\text {tot }}$ from $\mathrm{PW}$ by IAF. We found that the conditioning step before initiating the flotation process is important for $\mathrm{PAH}_{\text {tot }}$ recovery. A $\mathrm{PAH}_{\text {tot }}$ recovery of $93.67 \%$ was achieved at $30 \mathrm{~min}$ of conditioning and $20 \mathrm{~min}$ of flotation. We also found that in the presence of Tween 80 during the conditioning step, $\mathrm{PAH}_{\text {tot }}$ have a tendency to reach the water-air surface. It was disclosed that the addition of ethanol in PW during the conditioning has reduced both the conditioning time from $30 \mathrm{~min}$ to $10 \mathrm{~min}$ and the flotation time from $20 \mathrm{~min}$ to $12 \mathrm{~min}$, which is beneficial from an economic standpoint. The effect of ethanol on the flotation kinetics of $\mathrm{PAH}_{\mathrm{tot}}$ was explained well by the Higuchi model.
\end{abstract}

Keywords: produced water, polycyclic aromatic hydrocarbons, induced air flotation, Tween 80, ethanol, kinetics, environment

*e-mail: schwarz@tuzvo.sk 


\section{Introduction}

Produced water (PW), the largest waste stream generated in the petrochemical industry, is one of the major technical, environmental, and economic problems associated with oil and gas production $[1,2]$. The properties of PW are dependent on the geographic location of the field, the geological host formation, and the type of hydrocarbon produced, as well as the reservoir lifetime [1]. This kind of water can limit the productive life of the oil and gas wells and can cause severe problems, including the corrosion of tubular and fines migratatic loading [2,3]. A great deal of scientific research has been carried out to determine the consequences of long-term exposure of PW on the environment, and to develop an effective and inexpensive separation method [4-8]. Some of this research has given alarming results $[1,8]$. Among those alarming compounds, polycyclic aromatic hydrocarbons (PAHs) are considered to be the largest contributor to offshore PW toxicity $[4,8]$.

The analysis of PW discharged into the Mediterranean Sea (at Bejaia, Algeria) reveals the presence of a considerable amount of total PAHs $\left(\mathrm{PAH}_{\text {tot }}\right)$ at concentrations of about $3243 \mathrm{mg} / \mathrm{L} \mathrm{[8].}$ Algerian Decree No. 26 (23 April 2006), regulating the discharge of industrial effluents into the environment and issued by a joint decree of the Minister for the Environment, the Minister for Hydraulics, and the Minister for Health, set down the discharge limits of total hydrocarbons to $10 \mathrm{mg} / \mathrm{L}$ [9]. However, no regulatory limits are listed for PAHs, although $\mathrm{PAH}_{\text {tot }}$ concentration was higher [8] than the regulatory concentration limits set for total hydrocarbon PAHs [9]. Produced water also contains various inorganic species [8] with significantly higher concentrations [9]. In particular, oils that have a density close to that of water are extremely difficult to treat because they tend to form stable emulsions in water due to the waxes and other impurities present [10].

Induced air flotation (IAF) is utilized in the petrochemical industry for oil-water separation [11]. This method is usually preceded by chemical treatment of the sample to break oil-in-water emulsions in order to allow effective removal of contaminants $[8,12]$. The chemical reagents, called collectors such as Tween 80 , are added to adsorb selectively on surfaces of contaminants and increase their hydrophobicity [13]. Tween 80 is widely used in different fields, e.g., for the removal of petroleum hydrocarbons from wastewater by coagulation pretreatment or increasing of growth effect on microorganisms, their lipid accumulation and fatty acid composition [14-15]. By applying micelles of Tween 80, the production of clean water and recovery of valuable PAHs from PW could be achieved with low or no undesirable effect on the environment and aquatic species. Frothers are reagents that impact the air-water interfacial properties at low concentration by adsorption at the interface [13]. It seems that frothers have a greater effect on bubble size by affecting the bubble break-up process [16]. The alcohol frothers tend to produce relatively shallow froths that carry little water $[10,17]$. These factors play a significant role in the kinetic viability of the process and the recovery [18].

Flotation occurs from a true solution to a real problem encountered in industries; this is generally considered to be one of the main advantages of the flotation process, i.e., its ability to avoid consuming time. The duration of agitation or the conditioning time of the sample before the introduction of bubbles could have a positive influence on separation and it has been recognized for some time as an important methodology for improving the performance of the flotation process $[10,19]$. Nevertheless, some researchers have advised not using an introduction period, but adding the surfactant at the beginning of the flotation or even stepwise during the flotation process [10].

This paper aims to investigate and evaluate the effects of conditioning step on the recovery of $\mathrm{PAH}_{\text {tot }}$ from a real oilfield effluent, and the influence of both collector and frother on the conditioning step by constructing analytical methods for determining operating conditions. It should be noted that many important parameters such as the concentrations of both collector and frother were not considered in this work; only the effect of their presence on the recovery of $\mathrm{PAH}_{\text {tot }}$ by flotation process was studied. The flotation tests were carried out on a real oilfield effluent at $\mathrm{pH} 2$, already optimized in the presence of Tween 80 at a test concentration of $0.5 \%(\mathrm{~V} / \mathrm{V} \%)$ (non-ionic collector). The effect of ethanol at a test dosage of $0.5 \mathrm{~mL} / 1000 \mathrm{~mL}$ of $\mathrm{PW}$ on the flotation kinetics of $\mathrm{PAH}_{\text {tot }}$ was studied; the first-order kinetics and the Higuchi model for the flotation of $\mathrm{PAH}_{\text {tot }}$ in the presence of ethanol at different conditions and times were proposed. Flotation tests were carried out in a conventional mechanically agitated cell (Denver D-12, Laboratory Flotation Machine, Metso Minerals Industries, Danville, USA).

\section{Material and Methods}

\section{Experimental Design}

\section{Sites and Sampling}

Produced water was obtained from the SONATRACH Company of Bejaia, Algeria. Samples were collected in situ, at the outlet of hydrocarbon storage tank, and stocked in amber glass bottles in order to prevent the photodegradation of organic matter. The basic physical properties and chemical composition of a sample of these real oilfield effluents is shown in Table 1, and the analytical methods were detailed in a previous work [8]. 
Table 1. Main physical and chemical characteristics of PW.

\begin{tabular}{|c|c|}
\hline Parameters & Value \\
\hline $\mathrm{pH}$ & $5.13-6.78$ at $25^{\circ} \mathrm{C}$ \\
\hline Density & $1576 \mathrm{~kg} / \mathrm{cm}^{3}$ at $25^{\circ} \mathrm{C}$ \\
\hline Conductivity & $83.62 \mathrm{mS} / \mathrm{cm}$ at $20^{\circ} \mathrm{C}$ \\
\hline Turbidity & $92.67 \mathrm{FTU}$ \\
\hline Suspended Matters & $562 \mathrm{mg} / \mathrm{L}$ \\
\hline Hydrotimetric title & $12.8 \mathrm{meq} / \mathrm{L}$ \\
\hline Alkalinity & $0 \mathrm{mg} / \mathrm{L}$ \\
\hline Full alkalinity & $10 \mathrm{mg} / \mathrm{L}$ \\
\hline COD & $734 \mathrm{mg} / \mathrm{L} \mathrm{O}_{2}$ \\
\hline $\mathrm{Cl}^{-}$ & $1015.3 \mathrm{mg} / \mathrm{L}$ \\
\hline $\mathrm{NaCl}$ & $1673.1 \mathrm{mg} / \mathrm{L}$ \\
\hline $\mathrm{Fe}^{3+}$ & $0.042 \mathrm{mg} / \mathrm{L}$ \\
\hline $\mathrm{Pb}^{2+}$ & $4.91 \mathrm{mg} / \mathrm{L}$ \\
\hline $\mathrm{Cr}^{6+}$ & $0.135 \mathrm{mg} / \mathrm{L}$ \\
\hline $\mathrm{Ag}^{+}$ & $0.0613 \mathrm{mg} / \mathrm{L}$ \\
\hline $\mathrm{Ba}^{2+}$ & $0.91 \mathrm{mg} / \mathrm{L}$ \\
\hline $\mathrm{Li}^{+}$ & $0.0185 \mathrm{mg} / \mathrm{L}$ \\
\hline TOC & $93.83 \mathrm{mg} / \mathrm{L}$ \\
\hline $\mathrm{PAH}_{\text {tot }}$ & $3243 \mathrm{mg} / \mathrm{L}$ \\
\hline
\end{tabular}

\section{Chemicals}

Hydrochloric acid ( $\mathrm{HCl}$ ) 35-37\%, sodium hydroxide $(\mathrm{NaOH})$, and non-ionic collector (Tween 80) were obtained from BIOCHEM Chemopharma, (Montreal, Canada). Ethanol $\left(\mathrm{C}_{2} \mathrm{H}_{6} \mathrm{O}\right) 96 \%(\mathrm{~V} / \mathrm{V} \%)$ was obtained from SIGMA-ALDRICH. Naphthalene $\left(\mathrm{C}_{10} \mathrm{H}_{8}\right)$ was obtained from PANREAC QUIMICA SA (Spain).

\section{Flotation Tests}

The flotation tests were carried out on a real oilfield PW, in a Denver laboratory cell of $2 \mathrm{~L}$ capacity under the following conditions:

- Room temperature.

- pH 2.

- Impeller speed of 750 revolutions per minute (rpm).

- Tween 80 at a test concentration of $0.5 \%$ in ultra pure water (V/V \%).

- Ethanol at a test dosage of $0.5 \mathrm{~mL} / 1000 \mathrm{~mL}$ of PW.

First, a set of the flotation tests was performed to investigate the effect of the conditioning step on the flotation of $\mathrm{PAH}_{\text {tot }}$. Tween 80 was used as the collector, at a test concentration of $0.5 \%(\mathrm{~V} / \mathrm{V} \%)$, and was added in order to destabilize the oil-water emulsion. In this study, no frother (ethanol) was used. The tests were carried out at different conditioning times of 10, 20, and 30 minutes. The flotation time was the same for each test, at 20 minutes. At the end of the process, the volume of the pulps was measured and the recovery of $\mathrm{PAH}_{\text {tot }}$ was calculated.

In the second set of the flotation tests, the process was performed to determine the effect of Tween 80 at a test concentration of $0.5 \%(\mathrm{~V} / \mathrm{V} \%)$, on the flotation kinetics of $\mathrm{PAH}_{\text {tot }}$ during the conditioning step. Each $5 \mathrm{~min}, 5 \mathrm{~mL}$ of samples were taken until $30 \mathrm{~min}$ of stirring and the concentrations of $\mathrm{PAH}_{\text {tot }}$ were measured.

The third set of the flotation tests was performed to study the effect of ethanol on the flotation kinetics of $\mathrm{PAH}_{\text {tot }}$ during the conditioning step and its effect on both conditioning and flotation times. Three flotation tests were carried out at the conditioning times of $5 \mathrm{~min}, 10 \mathrm{~min}$, and $20 \mathrm{~min}$, respectively, with the initial concentrations of $\mathrm{PAH}_{\text {tot }}$ in the three samples of $\mathrm{PW}$ of $4.68 \mathrm{mg} / \mathrm{L}, 4.69 \mathrm{mg} / \mathrm{L}$, and $10.48 \mathrm{mg} / \mathrm{L}$. Tween 80 and ethanol were added at a test concentration. The flotation time was the same for each test: $20 \mathrm{~min}$. For each $2 \mathrm{~min}$ of flotation time, $5 \mathrm{~mL}$ of samples were taken until the end of the process and the concentrations of $\mathrm{PAH}_{\text {tot }}$ were measured.

The details of the flotation steps carried out on the PW sample are illustrated by the diagram represented in Fig. 1.

\section{Data Analysis}

UV-visible spectroscopy was used for qualitative and quantitative analysis as per the methods of Weide et al. and Monakhovaet et al. [20, 21] by measuring the UV absorbance of a sample containing PAHs to quantify the total PAHs $\left(\mathrm{PAH}_{\text {tot }}\right)$ via calibration as described by Mistry [22]. The calibration curve for naphthalene was established by obtaining optical densities on a series of dilutions made from the $100 \mathrm{mg} / \mathrm{L}$ solution in water-96\% ethanol mixture $(\mathrm{V} / \mathrm{V} \%)$ at a wavelength of $220 \mathrm{~nm}[8,22]$ (coefficient of regression, $\mathrm{R}^{2}=0.996$ ), measured on a Single Beam UV-Vis Spectrophotometer (SHIMADZU Model SpectroScan 30, Biotech Engineering Management Co, Ltd, UK).

Samples were filtered onto a filter paper of $1 \mu \mathrm{m}$. The dilutions were made on $0.5 \mathrm{~mL}$ of samples and transferred into glass pill dispensers to which were added $0.5 \mathrm{~mL}$ of $96 \%$ ethanol in order to form water- $96 \%$ ethanol mixtures $(\mathrm{V} / \mathrm{V} \%$ ) for analysis by UV-Vis spectroscopy; similarly, we established the naphthalene calibration curve in water-96\% ethanol (V/V\%). Samples were calculated from concentration dosages determined from optical densities measured at a wavelength of $220 \mathrm{~nm}$, on the calibration curve for naphthalene.

Concentration analysis is carried out for the recovered $\mathrm{PAH}_{\text {tot }}$. Calculating the removal efficiency of $\mathrm{PAH}_{\text {tot }}$ is done as a percentage of weight [23], as: 


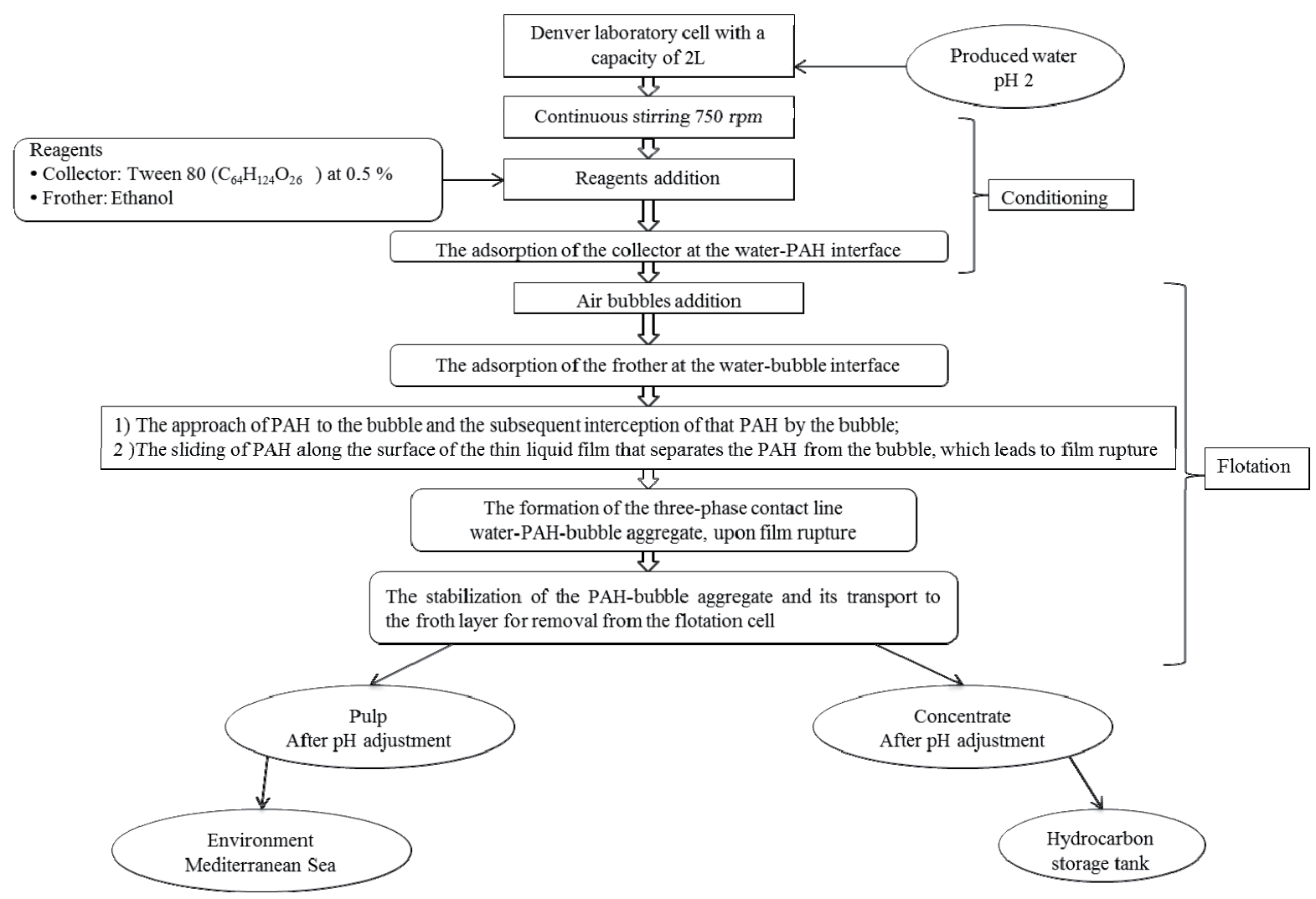

Fig. 1. Diagram illustrating the summary of the flotation steps.

$$
\operatorname{Rep}=\left[1-\left(\frac{\mathrm{Cp} * \mathrm{Vp}}{\mathrm{Ci} * \mathrm{Vi}}\right)\right] \times 100 \%
$$

where $\mathrm{C}_{\mathrm{i}}$ and $\mathrm{C}_{\mathrm{p}}$ are concentrations of $\mathrm{PAH}_{\text {tot }}$ in the $\mathrm{PW}$ and the pulp, respectively, and $\mathrm{V}_{\mathrm{i}}$ and $\mathrm{V}_{\mathrm{p}}$ are volumes of the PW and the pulp, respectively.

Regression model of the data is plotted using Microsoft Office Excel to describe the effect of the conditioning step and of both Tween 80 and ethanol on the flotation of $\mathrm{PAH}_{\text {tot }}$, and the flotation kinetics of the $\mathrm{PAH}_{\text {tot }}$ at different conditioning times.

\section{The Kinetics Study of Flotation of $\mathrm{PAH}_{\text {tot }}$}

To describe the kinetics of $\mathrm{PAH}_{\text {tot }}$ flotation, mathematical models such as first-order and Higuchi model were used [24]. The criterion for selecting the most appropriate model was based on a goodness-of-fit test.

First-order: $\ln \left(\frac{C_{t}}{C_{f}}\right)=-k t$

where $\mathrm{k}\left(\mathrm{min}^{-1}\right)$ is the flotation rate constant;

Higuchi Model: $\frac{\mathrm{C}_{\mathrm{t}}}{\mathrm{C}_{\mathrm{f}}}=\mathrm{K}_{\mathrm{H}} \mathrm{t}^{0.5}$ where $\mathrm{K}_{\mathrm{H}}$ is the flotation rate constant for the Higuchi Model, $\mathrm{C}_{\mathrm{t}}(\mathrm{mg} / \mathrm{L})$ is the concentration of the $\mathrm{PAH}_{\text {tot }}$ at any time, $\mathrm{C}_{\mathrm{f}}(\mathrm{mg} / \mathrm{L})$ is the final concentration of the $\mathrm{PAH}_{\text {tot }}$ at the end of the flotation process, beyond which the concentration of the $\mathrm{PAH}_{\text {tot }}$ does not change appreciably.

\section{Results and Discussion}

\section{Effect of Conditioning Time on the Recovery of $\mathrm{PAH}_{\text {tot }}$}

Conditioning time is the contact and mixing time between PAHs and flotation reagents. Since generally an increase in conditioning time can enhance and benefit the flotation process, the effect of conditioning time was determined. The stirring speed was chosen to be $750 \mathrm{rpm}$ because at this speed we observed that the majority of particles were kept in suspension without an overly turbulent pulp froth interface, and no frother was added. Fig. 2 shows that the conditioning step before injection of air in the flotation cell, mainly after the addition of Tween 80 (collector), at a test concentration of $0.5 \%$, acts directly on the flotation process. At $10 \mathrm{~min}$ of conditioning of the pulp, no flotation of PAHs was observed. It may be that $10 \mathrm{~min}$ were not sufficient for the formation of PAH-Tween 80 aggregates, or PAHTween 80 aggregates were formed but did not attach to the bubbles. 


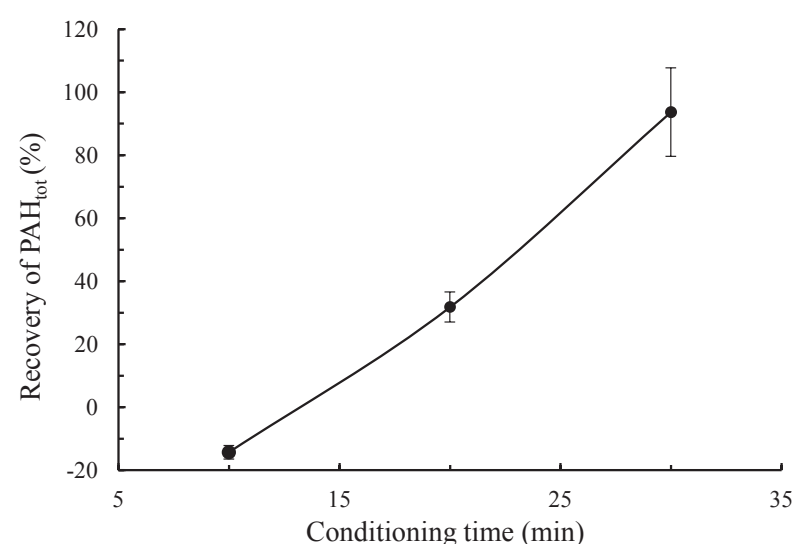

Fig. 2. Effect of conditioning time on the recovery of $\mathrm{PAH}_{\text {tot }}$

The increase in the conditioning time from 10 to 20 or even 30 min caused a measurable increase in $\mathrm{PAH}_{\text {tot }}$ recovery. The uniform distribution of Tween 80 molecules within the pulp, before injection of air bubbles, and their adsorption onto the surface of $\mathrm{PAH}_{\text {tot }}$ molecules was favored with increasing conditioning at $20 \mathrm{~min}$ and $30 \mathrm{~min}$ a $\mathrm{PAH}_{\text {tot }}$ recovery of $31.8 \%$ and $93.67 \%$, respectively, which has been calculated as described previously [8]. These results show that the time required for the Tween 80 molecules to adsorb onto the PAH surfaces and to make them hydrophobic, during the conditioning step, was to be around $30 \mathrm{~min}$. Longer conditioning times were usually more effective, because PAHs molecules have more opportunity for contact with both Tween 80 molecules and bubbles.

Wang et al. [25] and Firouzi et al. [26] reported that the typical induced air bubble diameter is approximatively between 100-1000 $\mu \mathrm{m}$. This implies that IAF has a greater bubble-rise velocity. The greater bubble-rise rate could, however, have an adverse effect on recovery. This is because faster-rising bubbles may redisperse the PAH-Tween 80 complex aggregates, on the one hand, and increase the contact time between PAH-Tween 80 aggregates and bubbles because of the increased induction time. On the other hand, it may have a direct effect on the conditioning time. To decrease bubble diameters and improve recovery, researchers have opted for the addition of frothers or/and inorganic salts $[26,27]$.

Furthermore, the natural presence of $\mathrm{NaCl}$ at greater concentration in this real oilfield effluent, at $1673.1 \mathrm{mg} / \mathrm{L}$ (Table 1), probably challenges the bubble diameters produced by IAF machine. Studies carried out by several researchers have demonstrated that some salts have been proven to affect the surface tension of bubble and inhibit bubble coalescence above a certain concentration [27]. Xu et al. [27] have reported that in the presence of $\mathrm{NaCl}$, the surface tension of air bubbles decreased, which leads to a decrease in their size. In this study, the effect of $\mathrm{NaCl}$ (naturally present in $\mathrm{PW}$ ) on PAH recovery has not yet been addressed.

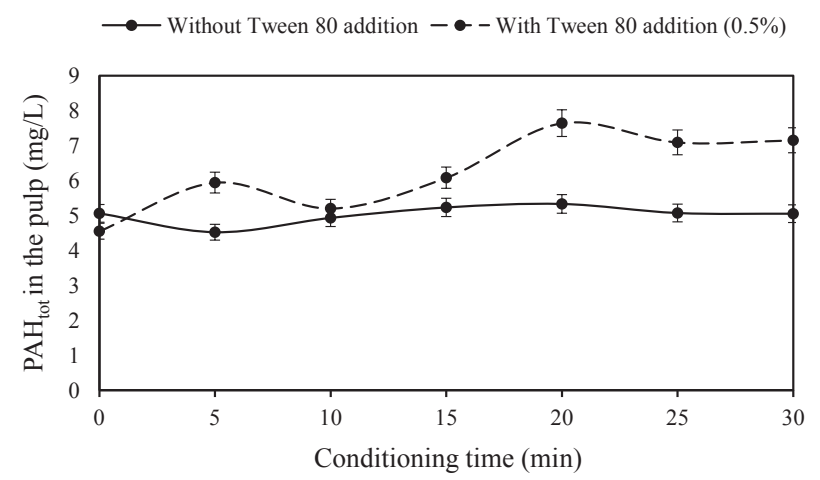

Fig. 3. Effect of Tween 80 on the flotation kinetics of $\mathrm{PAH}_{\text {tot }}$ during the conditioning step

\section{Effect of Tween 80 on the Flotation Kinetics of $\mathrm{PAH}_{\text {tot }}$ during the Conditioning Step}

Flotation depends on the surface characteristics of the oil; its overall effectiveness is greatly increased when chemical agents are used. Tween 80 was used in this study as collector at test concentration. The major reason for using Tween 80 is its ability to enhance the solubility of hydrophobic organic compounds by partitioning them into the hydrophobic cores of Tween 80 micelles [28]. A set of flotation tests has been established to investigate the role of Tween 80 on the flotation kinetics of PAHs during the conditioning step.

However, any emulsion must first be broken and the oil droplets grown before the flotation process takes place. The emulsion destabilization is brought about by adding Tween 80 [29]. The data (Fig. 3) showed that the addition of Tween 80 affects the flotation kinetics of $\mathrm{PAH}_{\text {tot }}$ molecules during the conditioning step well before the introduction of air bubbles.

In the absence of Tween 80, the quantification of $\mathrm{PAH}_{\text {tot }}$ in the samples collected at the surface of the pulp did not show any difference in the $\mathrm{PAH}_{\text {tot }}$ concentrations with time (Fig. 3). Effectively, heavy oil has a density close to that of water and tends to form a stable emulsion [1]. In addition, because of the complexity of the PW medium (Table 1), it was probable that PAH molecules, which were either trapped by the organic matters or at the free state in PW, have a low tendency to reach the water-air interface (the surface of the pulp).

Tween 80 affects the interfacial tension between PAHs and water [28]. The Tween 80 molecules have no residual electric charge. Therefore, their adsorptions onto PAHs were governed by hydrophobic interactions [30]. According to the obtained results, the addition of Tween 80 had led to the formation of a soluble PAHTween 80 aggregate with hydrophobic end, created by the hydrocarbon chain of Tween 80 , oriented at the water-air interface [31], which explains the accumulation of PAH molecules at the water-air interface during the first $20 \mathrm{~min}$ and stabilization until $30 \mathrm{~min}$ of the conditioning step. 


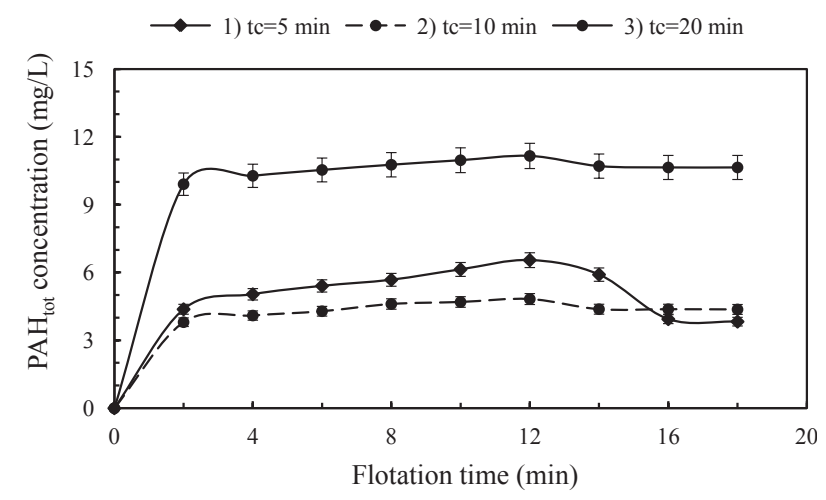

Fig. 4. Effect of ethanol on the flotation kinetics of $\mathrm{PAH}_{\text {tot }}$ at different conditioning times $\left(\mathrm{t}_{\mathrm{c}}\right)$.
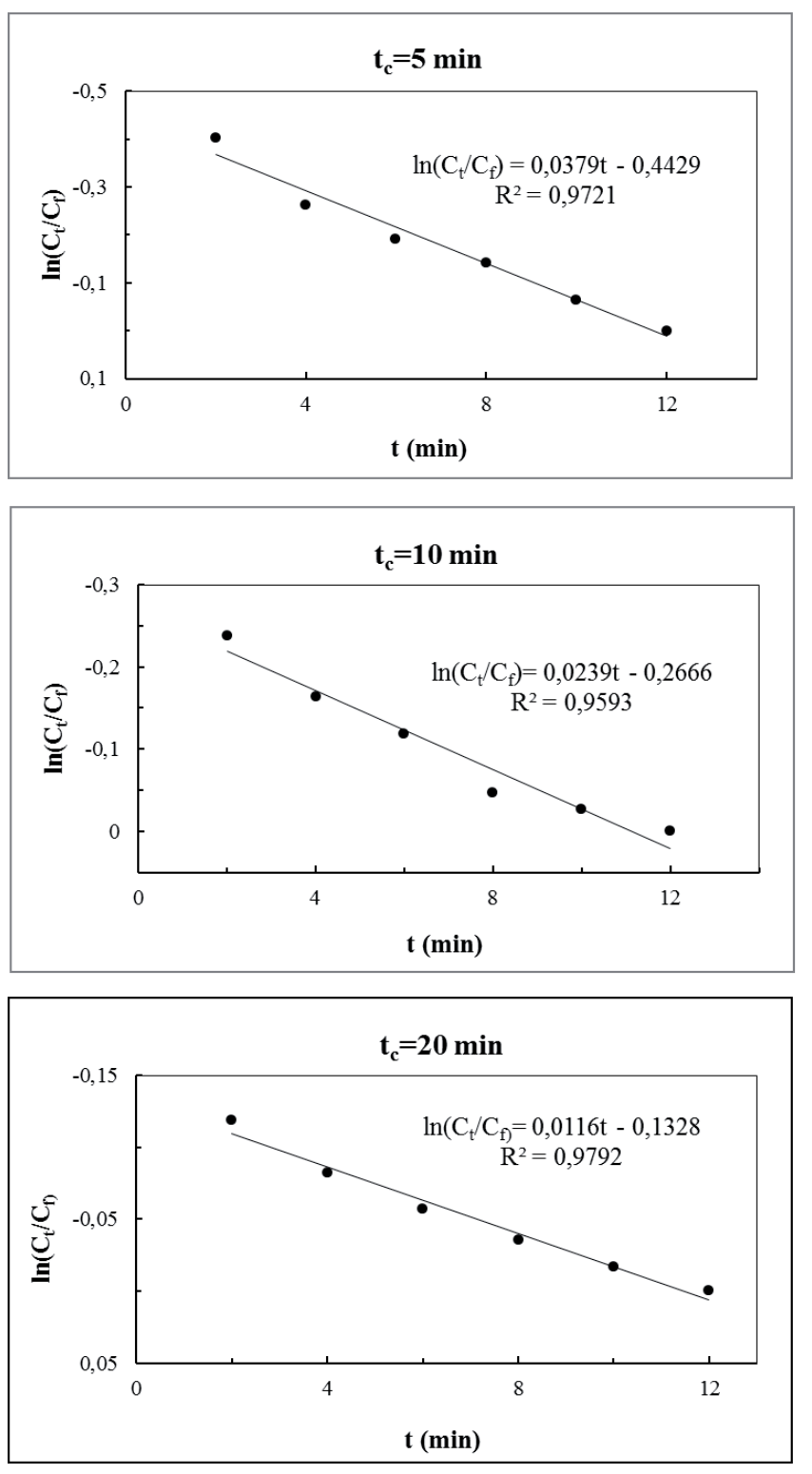

a)
Effect of Ethanol on the Flotation Kinetics of $\mathrm{PAH}_{\text {to }}$ at Different Conditioning Times

Ethanol contains the hydrophilic group $\mathrm{OH}$, which has strong hydrophilic properties and is very weaklyadsorbed on minerals (with the exception of naturally hydrophobic compounds such as PAHs) [18]. Ethanol molecules concentrate at the surface layer of air bubbles, which reduces their sizes and leads to an increase in the specific area air-water for the molecules attachment [32]. Small bubble size is important in controlling the number of bubbles that may be attached to particles. Also, large bubbles could break the PAH-Tween 80 aggregates and produced turbulence, preventing its flotation [33].
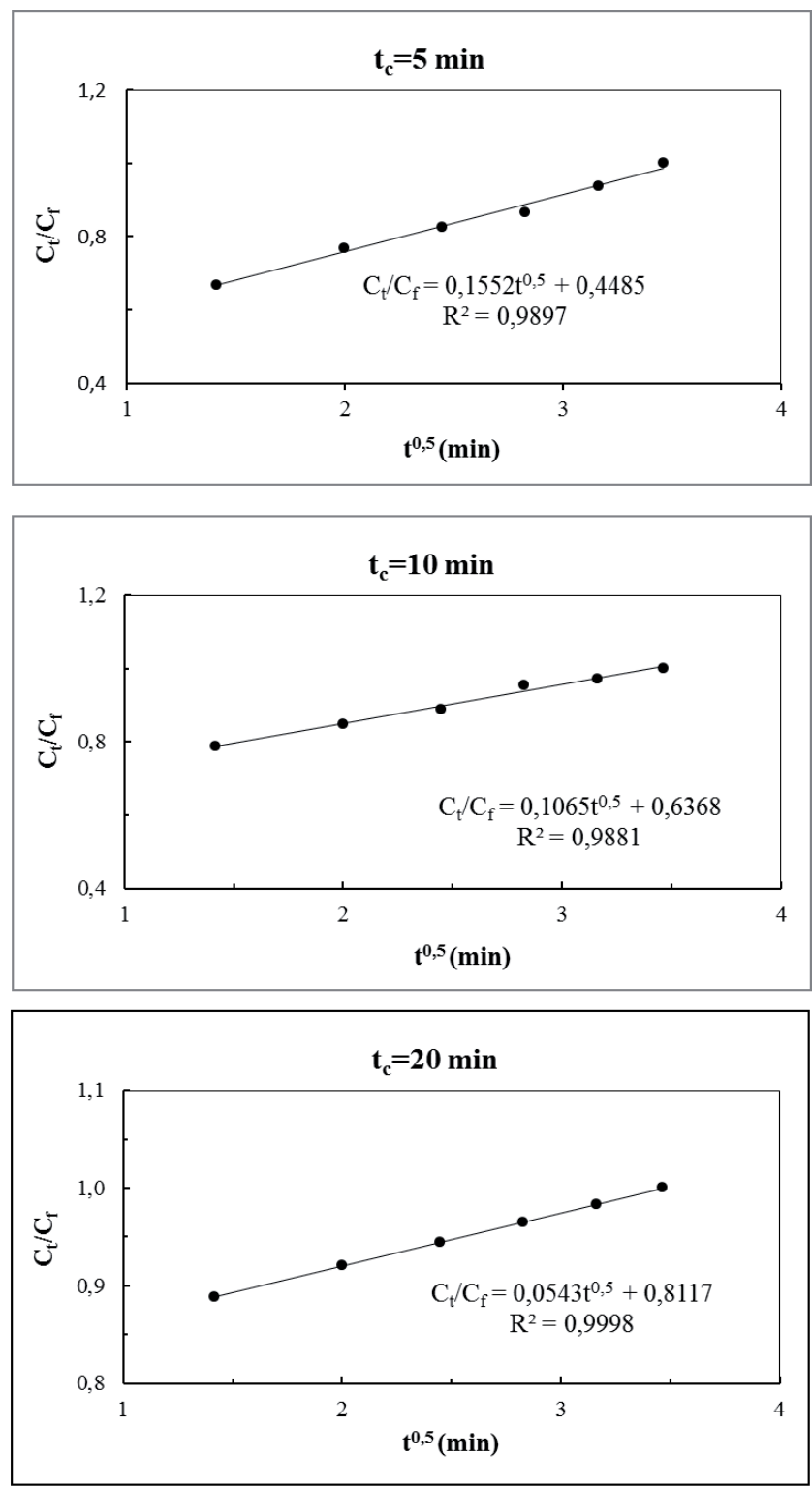

b)

Fig. 5. Mathematical models describing the effect of ethanol on the flotation kinetics of $\mathrm{PAH}_{\text {tot }}$ at different conditioning times ( $\left.\mathrm{t}_{\mathrm{c}}\right)$ : a) first-order kinetics and b) Higuchi model 
Experiments were carried out to study the effect of ethanol (frother) on the conditioning time and recovery of PAHs. Our results showed that recovery rates improved when a frother was used (Fig. 4). The addition of ethanol in the flotation pulp significantly increases the kinetics of the flotation of PAHs. The presence of ethanol reduced the flotation time of $\mathrm{PAH}_{\text {tot }}$ from $20 \mathrm{~min} \mathrm{[8]} \mathrm{to} 12 \mathrm{~min}$. Researchers have reported that large bubbles have a strong rise velocity, hence contact between the PAH molecules and the bubbles in the pulp was practically low [33]. Indeed, the diminution of the flotation time of $\mathrm{PAH}_{\text {tot }}$ can be explained by the fact that the use of ethanol had led to the production of finer bubbles due to lowering the surface tension of the pulp [34]. This led to the reduction of the induction time, that is, they have allowed colliding PAH-Tween 80 aggregates and bubbles to establish contact more rapidly [32, 34] for all three flotation tests at different conditioning times. However, after $12 \mathrm{~min}$ of aeration (flotation step), it was noticed that the concentration of $\mathrm{PAH}_{\text {tot }}$ in the concentrate was almost constant for flotation tests 2 and 3 until the end of the process, which was due to the stability of the froth above the flotation cell. Finally, high bubble density had promoted good flotation of $\mathrm{PAH}_{\text {tot }}$ by increasing the probability of $\mathrm{PAH}$ bubble encounter and by making more bubbles available for attachment to each particle.

For flotation test 1 ( $5 \mathrm{~min})$ we observed after $12 \mathrm{~min}$ of flotation a notable decrease of $\mathrm{PAH}_{\text {tot }}$ concentrations (compared to tests 2 and 3 with longer conditioning times), which remained low during the next $4 \mathrm{~min}$ before stabilization until the end of the process. This sudden decrease of $\mathrm{PAH}_{\text {tot }}$ concentrations was due to the instability of the froth. The contact PAH-bubble was unstable; the $\mathrm{PAH}_{\text {tot }}$ molecules fall down in the bottom of the flotation cell. Although there is not a general theory to describe the behavior of the froth [32], it is apparent that the use of a frother in IAF led to further stabilizing the foam layer [34]. The detachment of $\mathrm{PAH}$ molecules following the flotation process can probably be explained by the fact that the conditioning time (5 $\mathrm{min}$ ) was not sufficient to distribute uniformly the ethanol molecules in the PW before introducing bubbles, and that just after the introduction of air and the important turbulence existing in the flotation cell, the ethanol molecules did not all adsorb on the surface layer of the bubbles. But this was done gradually during the flotation, which was justified by the stability of froth after $16 \mathrm{~min}$ of flotation until the end of the process. In general, the frother determines the rate of flotation in almost every flotation system and the selection of the frother must always be in agreement with flotation kinetics [35].

According to this, as mentioned earlier, the firstorder flotation kinetics and the Higuchi model were employed to determine the mathematical model, which corresponds to describing the effect of ethanol on the flotation kinetics of $\mathrm{PAH}_{\text {tot }}$ at different conditioning times. The data was plotted in Fig. 5 for comparison.
It can be seen from Fig. 5a) that the first-order flotation kinetics showed a slower - and consequently more variable - flotation rate over time for the three set flotation tests at different conditioning times. It was in point of fact observed that the variations were linear with the correlation coefficients of $0.9721,0.9593$, and 0.9792 for, respectively, 5, 10, and $20 \mathrm{~min}$ of conditioning.

The kinetics of flotation of $\mathrm{PAH}_{\text {tot }}$, in the same conditions described by the Higuchi model (Fig. 5b), showed a higher flotation rate $(\mathrm{k})$ over time for the three set flotation tests at different conditioning times. The increasing trend of $\mathrm{k}$ with conditioning time indicates an improved $\mathrm{PAH}_{\text {tot }}$ recovery with a decrease in flotation time (Fig. 4). We observed that the variations at 5, 10 , and $20 \mathrm{~min}$ of conditioning were linear with high correlation coefficients of $0.9897,0.9881$, and 0.9998 for, respectively, 5, 10, and $20 \mathrm{~min}$ of conditioning. Da Silva et al. [36] reported that the separation of oil from synthetic oilfield PW by IAF obeyed firstorder kinetics. Compared to the results obtained with the first-order kinetics, we emphasize again that the flotation kinetics of $\mathrm{PAH}_{\text {tot }}$ into the real oilfield $\mathrm{PW}$ by IAF responds to the Higuchi model for each flotation test [8].

\section{Conclusions}

IAF was applied on a real oilfield effluent (PW) to remove PAHs. This study evaluated the importance of the conditioning step on the removal efficiency of PAHs from PW, and the role of both Tween 80 and ethanol on efficiency of this process. The results confirm that the crucial role of this step is the flotation process. As discussed above, electrolytic salts are known to reduce bubble diameters, thus the natural presence of $\mathrm{NaCl}$ in PW at considerable concentration probably affects the bubble sizes. This suggests that the presence of $\mathrm{NaCl}$ may improve the removal efficiency of PAHs from PW by IAF. The conditioning step before the flotation process is important in the case of $\mathrm{PAH}_{\text {tot }}$ recovery from $\mathrm{PW}$. The applied conditioning times in the presence of Tween 80 resulted in $\mathrm{PAH}_{\text {tot }}$ recovery of $93.67 \%$. The addition of ethanol as frother reduced both the conditioning time from $30 \mathrm{~min}$ to $10 \mathrm{~min}$ and the flotation time from $20 \mathrm{~min}$ to $12 \mathrm{~min}$. These data indicate that less alcohol may be necessary to reduce processing time than was used previously, which is beneficial from an economic standpoint. A detailed study of flotation kinetics in the presence of ethanol based on the flotation of $\mathrm{PAH}_{\text {tot }}$ at different conditioning times showed that the process followed the Higuchi model.

\section{Acknowledgements}

We thank all who have contributed in this humble work, including Technical University in Zvolen (Slovakia), Bejaia University (Algeria), and 
SONATRACH Company (Algeria). The paper is based on work performed under research contract VEGA $1 / 0377 / 17$ (Slovakia), whose support is gratefully acknowledged.

\section{Conflict of Interest}

The authors declare no conflict of interest.

\section{References}

1. FLORES R.M. Co-Produced Water Management and Environmental Impacts.In: Elsevier (Ed.)Coal and Coalbed Gas: Fueling the Future. Waltham - San Diego 437, 2014.

2. HOSNY R., FATHY M., RAMZI M., MOGHNY T.A., DESOUKY S.E.M., SHAMA S.A. Treatment of the oily produced water (OPW) using coagulant mixtures. Egyptian Journal of Petroleum, 25, 391, 2016.

3. LIU Y., ZHANG Y., YUANA J. Influence of produced water with high salinity and corrosion inhibitors on the corrosion of water injection pipe in Tuha oil field. Eng Failure Analysis, 45, 225, 2014.

4. ZHENG J., CHEN B., THANYAMANTA W., HAWBOLDT K., ZHANG B., LIU B. Offshore produced water management: A review of current practice and challenges in harsh/Arctic environments. Marine Pollution Bulletin 104, 7, 2016.

5. ALZAHRANI S., MOHAMMAD A. W. Challenges and trends in membrane technology implementation for produced water treatment: A review. Journal of Water Process Engineering, 4, 107, 2014.

6. MOTTA A., BORGES C., ESQUERRE K., KIPERSTOK A. Oil Produced Water treatment for oil removal by an integration of coalescer bed and microfiltration membrane processes. J Membrane Sci, 469, 371, 2014.

7. PARDUE M.J., CASTLE J.W., RODGERS J.H., HUDDLESTON G.M.Jr, Treatment of oil and grease in produced water by a pilot-scale constructed wetland system using biogeochemical processes. Chemosphere, 103, 67, 2014.

8. CHEBBI S., BELKACEMI H., MERABET D. Physicochemical Characterization and Kinetic Study of Flotation Process Applied to the Treatment of Produced Water. Journal of Environmental and Analytical Toxicology, 6, 362, 2016.

9. Algerian Decree Regulating the discharge of industrial liquid effluents in the environment, Official Journal of the Algerian Republic, No 26, 2006.

10. RAWLINS C.H., LY CH. Mechanisms for Flotation of Fine Oil Droplets. In: Separation Technologies for Minerals, Coal, and Earth Resources (Ed. Young C. A., Luttrell G.H) Society for mining, Metallurgy, and Exploration, Inc., Englewood, Colorado, USA, 307, 2012.

11. PAINMANAKUL P., SASTARAVET P., LERSJINTANAKARN S., KHAODHIAR S. Effect of bubble hydrodynamic and chemical dosage on treatment of oily wastewater by Induced Air Flotation (IAF) process. Chemical Engineering Research and Design, 88, 693, 2010.

12. SATHTHASIVAM J., LOGANATHAN K., SARP S. An overview of oil-water separation using gas flotation systems. Chemosphere, 144, 671, 2016.
13. KOSIOR D., ZAWALA J., NIECIKOWSKA A., MALYSA $\mathrm{K}$. Influence of non-ionic and ionic surfactants on kinetics of the bubble attachment to hydrophilic and hydrophobic solids. Colloid Surfaces A 470, 333, 2015.

14. HOSEINI S.M., SALARIRAD M.M., MOGHADDAM M.R.A. TPH removal from oily wastewater by combined coagulation pretreatment and mechanically induced air flotation. Desalination and Water Treatment, 53 (2), 300, 2015.

15. TAOKA Y., NAGANO N., OKITA Y., IZUMIDA H., SUGIMOTO S., HAYASHI M. Effect of Tween 80 on the growth, lipid accumulation and fatty acid composition of Thraustochytriumaureum ATCC 34304. J. Biosci. Bioeng. 111, 420, 2011.

16. GUPTA A.K., BANERJEE P.K., MISHRA A., SATISH P., PRADIP, Effect of alcohol and polyglycol ether frothers on foam stability, bubble size and coal flotation. International Journal of Mineral Processing, 82, 126, 2007.

17. LAU E.V., FOO K.L., POH P.E. The Recovery of Oil from Oil/Sand Slurries in a Laboratory-Scale Flotation Cell. International Journal of Environmental Science and Development, 4, 351, 2013.

18. KHOSHDAST H., SAM A. Flotation Frothers: Review of Their Classifications, Properties and Preparation. The Open Mineral Processing Journal, 4, 25, 2011.

19. KOH P.T.L., SMITH L.K. The effect of stirring speed and induction time on flotation. Miner Eng 24, 442, 2011.

20. WEIDE T., GUSCHIN V., BECKER W., KOELLE S. MAIER S., SEIDELT S. Analysis of pure tar substances (polycyclic aromatic hydrocarbons) in the gas stream using ultraviolet visible (UV-Vis) spectroscopy and multivariate curve resolution (MCR). Applied Spectroscopy, 69 (1), 143, 2015.

21. MONAKHOVA Y.B., ASTAKHOV S.A., KRASKOV A., MUSHTAKOVA S.P. Independent components in spectroscopic analysis of complex mixtures. Chemometrics and Intelligent Laboratory Systems, 103 (2), 108, 2010.

22. MISTRY B.D. Chemistry (UV, JR, PMR, JJCNMR and Mass Spectroscopy). A Handbook of Spectroscopic Data, $1,2009$.

23. LAU E.V., FOO K.L., POH P.E. The Recovery of Oil from Oil/Sand Slurries in a Laboratory-Scale Flotation Cell. Int. J. Environ. Sci. Develop. 44 (4), 351, 2013.

24. SIEPMANN J., PEPPAS N.A. Higuchi equation: derivation, applications, use and misuse. Int. J. Pharm. 418, 6, 2011.

25. WANG L.K., SHAMMAS N.K., SELKE W.A., AULENBACH D.B. Flotation Technology. Humana Press, Springer Science \& Business Media 12, 2010.

26. FIROUZI M., HOWES T., NGUYEN A.V. A quantitative review of the transition salt concentration for inhibiting bubble coalescence. Advances in Colloid and Interface Science 222, 305, 2015.

27. XU Q., NAKAJIMA M., ICHIKAWA S. Effects of surfactant and electrolyte concentrations on bubble formation and stabilization. J. Colloid. Interface Sci. 332, 208, 2009

28. BAZIAR M., MEHRASEBI M.R., ASSADI A., FAZLI M.M., MAROOSI M., RAHIMI F. Efficiency of non-ionic surfactants - EDTA for treating TPH and heavy metals from contaminated soil. Journal of Environmental Health Science and Engineering, 11, 2, 2013.

29. HAYATI N., BADIEI A., SOLEIMANI E. Tweens demulsification effects on heavy crude oil/water emulsion. Arabian Journal of Chemistry, 9, S806, 2016. 
30. SANTHANALAKSHMI J., BALAJI S. Adsorption Studies of Nonionic Surfactants onto Polyvinyltoluene Microlatexes in Aqueous Medium. Journal of Colloid and Interface Science, 232 (2), 219, 2000.

31. LIU Z., LAHA S., LUTHY R.G. Surfactant Solubilization of Polycyclic Aromatic Hydrocarbon Compounds in SoilWater Suspensions. Water Sci. Technol. 23 (1-3), 475, 1991.

32. FARROKHPAY S. The significance of froth stability in mineral flotation. A review. Advances in Colloid and Interface Science, 166, 1, 2011.

33. AZGOMI F., GOMEZ C.O., FINCH J.A. Correspondence of gas holdup and bubble size in presence of different frothers. International Journal of Mineral Processing, 83, 1, 2007.
34. KYZAS G.Z., MATIS K.A. Electroflotation process: A review. Journal of Molecular Liquids, 220, 657, 2016.

35. LIU G., YANG X., ZHONG H. Molecular design of flotation collectors: A recent progress. Advances in Colloid and Interface Science, 246, 181, 2017.

36. DA SILVA S.S., CHIAVONE-FILHO O., DE BARROS NETO E.L., FOLETTO E.L. Oil removal of oilfieldproduced water by induced air flotation using nonionic surfactants. Desalination and Water Treatment, 56 (7), 1802, 2015. 
